\title{
Use of the Metacognitive English Language Learning Strategies Based on Personality Traits
}

\author{
Seyed Hossein Fazeli \\ Department of English Language Teaching, Abadan Branch, Islamic Azad University, Abadan, Iran \\ Email: fazeli78@yahoo.com
}

\begin{abstract}
The present study aims to find out the relationship between use of the Metacognitive English Language Learning Strategies (MELLSs) for learners of English as a foreign language based on personality traits, and the role of personality traits in the prediction of use of such Strategies. Four instruments were used, which were Adapted Inventory for Metacognitive English Language Learning Strategies based on Metacognitive category of Strategy Inventory for Language Learning (SILL) of Rebecca L. Oxfords (1990), A Background Questionnaire, NEO-Five Factors Inventory (NEO-FFI), and Test of English as a Foreign Language (TOEFL). Two hundred and thirteen Iranian female university level learners of English language as a university major in Iran, were asked to participate in this research work. The intact classes were chosen. The results show that however, there is a significant relationship between four traits of personality and use of the MELLSs, but personality traits cannot be as a strong predictor with high percent of contribution to predict use of the MELLSs.
\end{abstract}

Index Terms - metacognitive language learning strategies, English learning, personality traits

\section{INTRODUCTION}

Since individual differences have been identified as variables influencing language learning outcome (LarsenFreeman \& Long, 1991; Skehan, 1989); and as it was shown by the study of Marttinen (2008), the high percent of source of learners' knowledge comes from teacher; Horwitz (1988) encourages teachers to discover the prescriptive belief of their own students. Moreover, in order to provide successful instruction, teachers need to learn to identify and understand their students' individual difference, and even they need to become more aware that their teaching styles must be appropriate to their learners' strategies (Oxford \& Cohen, 1992).

Recently some studies tend to concentrate more on individual differences in strategy performance (e.g. Oxford, 1992, 1993; Toyoda, 1998). In such related studies, it was showed for strategy instruction to be affected; it should take all the variables into account (Oxford \& Crookball, 1989).

Since 1990s, there has been a growing interest on how personality correlates to the academic performance. Personality has been conceptualized at different levels of breadth (McAdams, 1992), and each of these levels include our understanding of individual understanding. Moreover, individuals are characterized by a unique pattern of traits, and some study shows successful language learners choose strategies to suit their personalities (Oxford \& Nyikos, 1989). In addition, since LLSs are not innate but learnable (Oxford, 1994), broad justifications have been offered for the evaluation of personality traits as a predictor of MELLSs.

In such way, the premise underlying line of this research is that success in MELLSs plays an important role in affecting learners' English language learning process.

\section{REVIEW OF THE LITERATURE}

The studies on individual and personality differences are a central theme in psychology as well as the other areas of social and behavior sciences (Saklofske \& Eysneck, 1998).

The examination of variation in human behavior is referred to as the study of individual differences (Ehrman \& Dornyei, 1998). Such study of individual differences includes many subsets of studies such as the study of personality differences (Hampson \& Colman, 1995), and personality factors that are important in development of linguistic abilities (Ellis, 1985). Psychologically, it is a truism that people are different in many fundamental ways, and learners are individuals, and there are infinitely variables (Skehan, 1989). In this manner, Horwitz (1999) points out "language learners are individuals approaching language learning in their own unique way" (p.558). In addition, individuals who are characterized as a particular psychological type, adopt different learning strategies (Brown, 2001).In such situation, the teachers must make the students aware of the range of the strategies they can adopt (Cook, 2008); and they must aware of the relationship between personality and academic performance (Cattel \& Butcher, 1968; Eysenck, 1967).

Foregoing has highlighted the main goal of the current study was to document how personality traits related to the MELLSs. In such situation, there are some possible ways looking at the MELLSs and their relationship with personality traits. The first is to see the use of the MELLSs as an outcome of personality traits. The second is to see them as having 
uni-directional causal role increasing personality traits. The third one is to see the relationship between the two as mutual, and causality is bi-directional.

\section{MeTHODOLOGY}

\section{A. Participants}

The descriptive statistics are such type of numerical representation of participants (Brown, J. D. 1996). The sample drawn from the population must be representative so as to allow the researchers to make inferences or generalization from sample statistics to population (Maleske, 1995). As Riazi (1999) presents "A question that often plagues the novice the researcher is just how large his sample should been order to conduct an adequate survey or study. There is, of course, no clear-cut answer" (pp.242-243). If sample size is too small, it is difficult to have reliable answer to the research questions. If sample is too large, it is difficulty of doing research. To leave a margin of about $20 \%$ for ineffectual questionnaires slightly bigger numbers were chosen. In this way, initially a total of two hundred fifty Iranian female university level learners of English language as a university major at the Islamic Azad University Branches of three cities which named Abadan, Dezful ,and Masjed-Solyman in Khuzestan province in south of Iran, were asked to participate in this research work. It must bear in mind that number of participants may affect the appropriateness of particular tool (Cohen \& Scott, 1996). The intact classes were chosen.

The chosen participants for this study were studying in third grade (year) of English major of B. A. degree. There was only female, ranging age from 19 to 28 (Mean=23.4, $\mathrm{SD}=2$ ). Their mother tongue was Persian (Farsi) which is the official language of Iran, according to Act 15 of the Iranian constitution.

The socio-economic status of participants, such as the participants' social background, and parents' level education controlled as well by questionnaire,. Based on some indicators such as the parents' socio-educational background and occupation, the participants were matched as closely as possible for socio-economic background to minimize the effect of social class. Accordingly, the participants were classified as a middle class. Moreover the most of the participants from the Islamic Azad University in Khuzestan province, Iran, have middle-class and similar socio-economic background.

Because of the nature of this work (regarding the use of English LLSs), a general English proficiency test for determining the proficiency level of participants in English was applied in order to minimize the effect of English language proficiency. As Jafarpour (2001) defines "the percent classification of subjects by the experimental test that corresponds to those by the criterion" (pp.32-33) (as cited in Golkar \& Yamini, 2007), top of subjects are 27\% and bottom of subjects are $27 \%$ (Golkar \& Yamini, 2007), the participant whom were classified as intermediate subjects, were asked to participate in the current study.

\section{B. Instrumentation in the Current Study}

Four instruments were used to gather data in the current study. They were:

1. Adapted Inventory for Metacognitive English Language Learning Strategies

The Strategy Inventory for Language Learning(SILL) of Rebecca L. Oxford (1990) is a kind of self-report questionnaire that has been used extensively by researchers in many countries, and its reliability has been checked in multiple ways, and has been reported as high validity, reliability and utility(Oxford, 1996). In addition, factor analysis of SILL is confirmed by many studies (Hsiao \& Oxford, 2002; Oxford, 1996; Oxford \& Burry-Stock, 1995).In this way, as Ellis (1994) believes Oxford's taxonomy is possibly the most comprehensive currently available. Several empirical studies have been found moderate intercorrelation between the items of six categories in SILL (Oxford \& Ehrman, 1995).

The SILL includes Memory Strategies(9 items), Cognitive Strategies(14 items), Compensation Strategies(6 items), Metacognitive Strategies(9 items), Affective Strategies(6 items), and Social Strategies(6 items).

Based on the Metacognitive category of SILL, the investigator adapted a questionnaire. In adaptation of each instrument from one language to another in research works, some problems occur, such as the problem of translation one questionnaire to another language (Perera \& Eysenck, 1984). As same as the other two questioners (NEO-FFI and Background Questionnaire), adapted MELLSs inventory was checked through back translation into English by three English teachers, and three psychologists who were fully proficient in both languages (English and Persian), in order to check the consistency with English version, and based on the pilot study was performed. The items were corrected until full agreement among the translators was achieved, and the pilot study confirms such translated items. In addition, the balance between spoken and written Persian was checked.

It must bear in mind that the translation/back translation is one of more effective ways to solve the equivalent concepts of translated and original version of one questionnaire (Behling \& Law, 2000), and one researcher can be ideal translator if she or he is fluent in target language.

In the case of such questionnaire, three psychologists, and three English teachers were asked to check the questionnaire from two points of view. Firstly, since both psychologists and linguists were fully proficient in both languages (English and Persian), they were asked to check the translated version of the questionnaire in order to check the consistency with English version of them. Secondly, since both the psychologists and English teachers were professional in related study of the questionnaire, they were asked to check the psychometrics of the questionnaire. 
After full agreement among the psychologists and linguists was achieved, and the pilot study confirms the items of such questionnaire, it was administrated in the main study.

2. Test of English as a Foreign Language (TOEFL)

Because of the nature of this work (regarding the use of English LLSs), TOEFL(Structure and Written Expression, and Reading Comprehension parts) as a general English proficiency test was used for determining the proficiency level of participants in English in order to minimize the effect of English language proficiency. The participant whom classified as intermediate subjects, were asked to participate in the current study.

3. A background questionnaire

The socio-economic status of participants, such as the participants' social background, and parents' level education was controlled as well by a background questionnaire. The middle class students were chosen.

4. NEO-Five Factors Inventory (NEO-FFI)

The Big Five Personality Questionnaire is based on the Big Five Factor Model of personality whose major proponents are Lewis Goldberg, Paul Costa, and Robert McCare. This theory proposes that five broad dimensions provide complete description of personality.

The questionnaire of the Big Five Factors is one of the most widely used personality assessment in the world. In addition, evidences indicate that Big Five is fairly stable over time (Costa \& McCare, 1988; Digman, 1989). Moreover factor structure resembling the Big Five Factors were identified in numerous sets of variables (Digman \& Inouye, 1986; Goldberg, 1981, 1990; John, 1990; McCare \& Costa, 1985; Saucier \& Goldberg, 1996). In addition, the scales of Big Five personality have proven to be a useful tool in a number of applied fields. In this way, the Big Five Factors Inventory has enjoyed wide spread popularity in applied organizational context. The reliability reported in the manual is adequate with mean of .78 across the five factors (Costa \& McCare, 1992).

The idea of major dimensions include much of personality is long standing (Norman, 1963). In addition, Digman and Inouye (1986) state "the domain of personality of personality descriptors is almost completely accounted for by five robust factors" (p.116). In this way, the Big Five Factors personality questionnaire can be as a satisfactory tool to assess the relationship between personality and a number of academic variables (Chamorro-Premuzie, Furnham \& Lewis, 2007). Despite the FFI enjoys international use, but the Big Five structure has not been accepted generally (Block, 1995 Eysenck, 1992, 1997; McAdams, 1992).

The dimensions composing the Big Five Factors (as cited in related literature by different dominant researchers such as Chamorro-Premuzie, Furnham \& Lewis, 2007; Costa \& McCare, 1992) are detailed as: a) Neuroticism represents the tendency to exhibit poor emotional adjustment, anxious, and pessimistic; b) Extraversion represents the tendency to be sociable and assertive, cheerful, active, upbeat, and optimistic; c) Openness to experiences (intellect) represents the tendency to imaginative, intellectually curious, imaginative, and artistically sensitive; d) Agreeableness is the tendency to be trusting, compliant, caring, gentle, compassionate, empathic, and cooperative; e) Conscientiousness represents the tendency to responsible, organized, hard-working, responsible, dependable, able to plan, organized, persistent, achievement oriented, purposeful, strong-willed, and determined.

The NEO-FFI is a sixty-item version of $\mathrm{S}$ form of the NEO-PI-R that is applied to measure the five domains of personality. It consists of five 12-item scales. Each of these sixty items includes five choices. As same as SILL procedure, the participants were asked to choice the statement which how true of them it is. They were told that answer must be in terms of how well the statement describes them. Also they were told that there is no right or wrong answer to these statements. The NEO-FFI is self-scoring, and paper and pencil survey. It is 5-point scale range from "Strongly Disagree" to "Strongly Agree". The choices are as: a) Strongly Disagree, b) Disagree, c) Neutral, d) Agree, e) Strongly Agree.

The adapted Persian version of NEO-FFI was used in the current study. The short form of NEO-FFI (Costa \& McCare, 1992) was translated into Persian language (Fathi-Ashtiani, 2009). Also it consists of sixty items, 12 items for each of the "Big Five" sub-scales.

\section{Sample of the Pilot Study}

The sample for the pilot study, as "A small-scale replica and a rehearsal of the main study" (Riazi, 1999, p.198), was selected so as it represents the entire sample for participants whom asked to participate in the main study. Since sample size in pilot study ranges from 20 to bigger of 65(Hinkin,1998), thirty nine female students university level learners of English language as a university major at Islamic Azad University Branches of three cities which named Abadan, Dezful ,and Masjed-Solyman were asked to participate in the pilot study. In this pilot study, the percent of participants from each branch is approximately equal to the others. They were told about the importance of the results of the pilot study.

\section{Reliability of the Instruments}

This section will explore the reliabilities of the three instruments: Adapted Inventory for Metacognitive English Language Learning Strategies, NEO-FFI, and TOEFL. Since Cronbach's alpha is one of the standard ways of expressing a test's reliability (Foster, 1998); and its coefficient is commonly used to describe the reliability factors of multi-point formatted questionnaires or scales; in such way, the reliabilities of our experimental measures were assessed by calculating Cronbach's alpha over the items of the three instruments across all the participants in the current study 
which were found .81 for Adapted Inventory for Metacognitive English Language Learning Strategies,.82 for NEO-FFI, and .80 for TOEFL. The reliability coefficient indicated the degree to which the results on a scale can be considered internally consistent, or reliable (De Vellis, 2003; Ghiasvand, 2008; Moemeni, 2007; Nunnally \& Bernstein, 1994). Such finding of reliabilities for the three instruments confirm the finding of reliabilities in the pilot study.

\section{E. Data Collection Procedures in the Main Study}

The data for the study described in this study was collected between September 2010 and November 2010 in Iran, at the Islamic Azad University Branches of three cities that are named Abadan, Dezful, and Masjed-Solyman. As stated these three cities are located in Khuzestan province in south of Iran.

All of the instruments were administrated during class time and based on the availability of the participants of third grade (year) at three stages. The researcher, himself, administrated all the instruments. All the participants participated in the main study, were explained the goals of the current study by the researcher. Also for each stage of administration, the researcher explained the instructions for answering the test and questionnaires before each of the instruments was administrated. All the explanation of the materials was performed through Persian language (which is the mother tongue of the participants).

To increase the credibility of the response, the participants were asked that they should be honestly in their answers, and they should not spend too much time on any of the items. The participants were also asked to ask any question or doubt it they had. After completion of answering the questionnaires, the respondents were asked whether they answer all the items or not; and whether they mark their response in correct spaces or not. In each of both states, if the participants did not answer all the items or not mark their responses in correct spaces, they were asked to revise those items, and answer those items or mark their responses in correct spaces.

1. Stage one

At this stage, the participants were asked to answer TOEFL test. Approximately 80 minutes were taken to answer the test. Such duration of time is as the duration of time was calculated in the pilot study (The first week).

2. Stage two

At the second stage, the respondents were asked to fill the Adapted Inventory for Metacognitive English Language Learning Strategies. The respondents were asked to respond to the questions within 5-10 minutes. The time that assigned for participants was determined according to the results obtained from the pilot study. Alongside Adapted Inventory for Metacognitive English Language Learning Strategies, Background Questionnaire was administrated (The second week).

3. Stage three

At this Stage, NEO-FFI was administrated. The time that assigned for the participants in order to complete NEO-FFI was determined according to the results obtained from the pilot study.10 - 15 minutes was enough to complete NEOFFI(The third week).

\section{F. Data Analysis}

After data collection, the data was entered onto databases (Excel and SPSS) to enable data analysis to be carried out.

The First procedure of data analysis includes Pearson Correlation that used to identify the strength and direction of the relationship between variables. As known to the researchers in the field, correlation does not imply causality, but it does provide a picture of relationships. The important point, the classification of strength of correlation is not well accepted among different researchers, and there are different classifications such as the classification suggested by Cohen, J. (1988), Delavar (2010), Ghiasvand (2008). In the current study, the classification that was suggested by Cohen, J. (1988) was chosen as criterion to interpret and discuss about the strength of the correlation. It is as table 1:

TABLE1:

THE CLASSIFICATION WAS SUGGESTED BY COHEN, J (1988)
\begin{tabular}{|l|l|}
\hline Level of Strength & Amount of the Strength \\
\hline Low & $\mathrm{r}=.10$ to .29 \\
\hline Medium & $\mathrm{r}=.30$ to .49 \\
\hline Strong & $\mathrm{r}=.50$ to 1 \\
\hline
\end{tabular}

The second procedure of data analysis includes Analysis of Variance (ANOVA) that is an analytic tool. In nonexperimental research, ANOVA does not show the same meaning as experimental research. In non-experimental research, ANOVA does not mean causality between the independent variables and the dependent variables when there is significant relationship. In this way, the use of ANOVA in non-experimental research is criticized if the goal is finding casual relationships (Johnson, 2001). Moreover the use of ANOVA in non-experimental is perfectly acceptable when the goal is not causality according to top statisticians (e.g. Johenson, 2001). In addition, ANOVA has been frequently used for many years in non-experimental research (Johnson, 2001).

In such way, correlation is used to find the degree and direction of the relationship between variables, and ANOVA test the significance of the relationship.

The third procedure of data analysis includes multiple regression analysis. As Newton and Rudestan (1999), point out it is used to find the relationship between multiple distributed independent variables and a single dependent variable. In 
such way, the researcher used multiple regression to identify among all the five independent variables the best predictors of the overall use of ELLSs use. In this procedure, stepwise method was used; and the interpretation of the stepwise method of multiple regression was based on the samples of Ghisvand, 2008; Kalantari, 2008; and Pallant, 2007.

\section{Results, DisCussion, AND CONCLUSION}

In the entire sample, the strategies in the Metacognitive category were the High frequently used, with a mean of 3.7( $\mathrm{SD}=.64)$ (Based on the Oxford'key, 1990).

The means were calculated in order to determine the mean of the each of five traits of personality among the total group of the respondents $(\mathrm{N}=213)$ (Table 2).

TABLE 2:

MEANS AND STANDARD DEVIATIONS (SD) OF THE FIVE TRAITS OF PERSONALITY IN THE CURRENT STUDY
\begin{tabular}{|l|l|l|l|}
\hline Personality Trait & N & Mean & SD \\
\hline Neuroticism & 213 & 23.0 & 8.3 \\
\hline Extraversion & 213 & 27.4 & 5.5 \\
\hline Openness to Experiences & 213 & 27.9 & 4.7 \\
\hline Agreeableness & 213 & 32.4 & 5.4 \\
\hline Conscientiousness & 213 & 34.7 & 6.3 \\
\hline
\end{tabular}

Table 2showed that the mean of the Conscientiousness trait (Mean=34.7, SD =6.3) was more than each of the means of the other four traits, and the mean of the Neuroticism trait (Mean=23.0, $\mathrm{SD}=8.3$ ) was less than each of the means of the other four traits.

The Pearson Correlation was performed to examine whether there is relationship between the Overall Metacognitive Strategy Use and the Five Traits of Personality (Table 3).

TABLE 3:

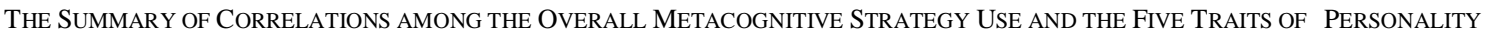

\begin{tabular}{|c|c|c|c|c|c|c|}
\hline & & Extraversion & Openness to Experiences & Agreea-bleness & Conscient-iousness & Neuro-ticism \\
\hline \multirow{3}{*}{$\begin{array}{l}\text { Metacognitive } \\
\text { Strategies }\end{array}$} & Pearson Correlation & $.166^{*}$ & $.265^{* 17}$ & .121 & $.372^{* *}$ & $-.182^{* * 2}$ \\
\hline & Sig. (2-tailed) & .015 & .000 & .078 & .000 & .008 \\
\hline & $\mathrm{N}$ & 213 & 213 & 213 & 213 & 213 \\
\hline
\end{tabular}

According to Table 3, the students' overall Metacognitive strategy use was significant positively correlated with the Openness to Experiences trait, and the Conscientiousness trait at the $\mathrm{p}<.01$ level (2-tailed), and the Extraversion trait at the $\mathrm{p}<.05$ level (2-tailed). The levels of correlations were found low for the Openness to Experiences trait, the Extraversion, and medium for the Conscientiousness trait. For the Agreeableness trait, the correlation was no significant (P>.05). For the Neuroticism trait, the students' overall Metacognitive strategy use was negatively correlated with it at the $\mathrm{p}<.01$ level (2-tailed). The level of correlation was found low. In Table 3, there were found both types of positive and negative correlations, but in both types of correlation, the level of correlation was found low (except in the case of the Conscientiousness trait that its correlation level was medium). Moreover, except the case of the Agreeableness trait, all types of correlations were significant at the $\mathrm{p}<.01$ or $\mathrm{p}<.05$ levels (2-tailed).

Table 3 indicated that based on increasing of the Extraversion trait level of the students, higher average of Metacognitive Strategies would be used, and based on decreasing of the Extraversion trait level, lower average of Metacognitive Strategies would be used. In such way, Table 3 showed that there was a meaningful significant positive relationship between the overall Metacognitive strategy use and the Extraversion trait $(\mathrm{r}=.166, \mathrm{p}<.05)$. The positive relationship implies that the more extraverted students use Metacognitive Strategies more.

Table 3 indicated that based on increasing of the Openness to Experiences trait level of the students, higher average of Metacognitive Strategies would be used, and based on decreasing of the Openness to Experiences trait level, lower average of Metacognitive Strategies would be used. In such way, Table 3 showed that there was a meaningful significant positive relationship between the overall Metacognitive strategy use and the Openness to Experiences trait $(\mathrm{r}=.265, \mathrm{p}<.01)$. The positive relationship implies that the students with higher level of Openness to Experiences trait use Metacognitive Strategies more.

Table 3 indicated that there was not a meaningful significant relationship between the overall Metacognitive strategy use and the Agreeableness trait.

Table indicated that based on increasing of the Conscientiousness trait level of the students, higher average of Metacognitive Strategies would be used, and based on decreasing of the Conscientiousness trait level, lower average of Metacognitive Strategies would be used. In such way, Table 3 showed that there was a meaningful significant positive relationship between the overall Metacognitive strategy use and the Conscientiousness trait $(\mathrm{r}=.372, \mathrm{p}<.01)$. The positive relationship implies that the more Conscious students use Metacognitive Strategies more.

Table 3 indicated that based on increasing of the Neuroticism trait level of the students, lower average of Metacognitive Strategies would be used. In such way, Table 3 showed that there was a meaningful significant negative 
relationship between the overall Metacognitive strategy use and the Neuroticism trait $(\mathrm{r}=-.182, \mathrm{p}<.01)$. The negative relationship implies that the more Neurotic students use Metacognitive Strategies less.

The multiple regression analysis, for all the five traits of personality (as independent variables) and the overall use of Metacognitive Strategies (as a dependent variable) were analyzed through the stepwise method. Out of the five traits of personality, only two variables entered the equation (Table 4).

TABLE 4:

THE MODEL SUMMARY OF THE EQUATION

\begin{tabular}{|l|l|l|l|l|l|}
\hline Model & Variables Entered & R & R Square & Adjusted R Square & Std. Error of the Estimate \\
\hline 1 & Conscientiousness & $.372^{\mathrm{a}}$ & .138 & .134 & .59207 \\
\hline 2 & $\begin{array}{l}\text { Openness to } \\
\text { Experiences }\end{array}$ & $.430^{\mathrm{b}}$ & .185 & .177 & .57720 \\
\hline
\end{tabular}

Stepwise (Criteria: Probability-of-F-to-enter $<=.050$, Probability-of-F-to-remove $>=.100$ )

Dependent Variable: Metacognitive Strategies

a. Predictors: (Constant), Conscientiousness

b. Predictors: (Constant), Conscientiousness, Openness to Experiences

According to Table 4, regression analysis has run up to two steps. In the first step, the Conscientiousness trait entered the equation that the Adjusted R-Square became .134. In the second step, when the Openness to Experiences trait entered the equation, the Adjusted R-Square increased up to .177. In other words, based on the Adjusted R-Square, the emerged model for the two independent variables with the Adjusted R-Square of .177, accounted for explaining about $17.7 \%$ of the variance of the students' overall Metacognitive strategy use.

TABLE 5:

THE RESULTS OF REGRESSIONAL ANOVAC OF THE EQUATION

\begin{tabular}{|c|c|c|c|c|c|}
\hline Model & Sum of Squares & df & Mean Square & $\mathbf{F}$ & Sig. \\
\hline 1 Regression & 11.852 & 1 & 11.852 & 33.810 & $.000^{\mathrm{a}}$ \\
\hline Residual & 73.966 & 211 & .351 & & \\
\hline Total & 85.819 & 212 & & & \\
\hline 2Regression & 15.854 & 2 & 7.927 & 23.793 & $.000^{\mathrm{b}}$ \\
\hline Residual & 69.964 & 210 & .333 & & \\
\hline Total & 85.819 & 212 & & & \\
\hline
\end{tabular}

Further, Table 5 (regressional ANOVA) showed that the effect was significant, and all the models had high $\mathrm{F}$ values $(\mathrm{F}=33.810, \mathrm{~F}=23.793, \mathrm{P}<.01)$. Therefore, it could be concluded that about $17.7 \%$ of changes in the students' overall Metacognitive strategy use was accounted for by the Conscientiousness and Openness to Experiences traits.

Table 5 indicated that the effect of the Conscientiousness and Openness to Experiences traits was significant at the p<.01 level. Remaining the three traits of personality did not enter the regression equation because of level of their errors were greater than .05 , and they had very weak effect in the prediction of the overall Metacognitive strategy use. In such way, rest of the contribution for the overall Metacognitive strategy use was unaccounted for.

TABLE 6:

THE UNSATNDERDISED COEFFICIENTSA, T TESTS AND SIGNIFICANCES FOR DIFFERENT MODELS PREDICTED OF THE EQUATION

\begin{tabular}{|l|l|l|l|l|l|}
\hline \multirow{2}{*}{ Model } & \multicolumn{2}{|l|}{ Unstandardized Coefficients } & Standardized Coefficients \\
\cline { 2 - 5 } & B & Std. Error & Sig. \\
\hline 1 (Constant) & 2.369 & .229 & & \\
Conscientiousness & .452 & .078 & .372 & 10.364 \\
\hline 2 (Constant) & 1.656 & .303 & & \\
Conscientiousness & .416 & .077 & .342 & 5.815 \\
Openness to Experiences & .352 & .101 & .000 & .000 \\
\hline
\end{tabular}

a. Dependent Variable: Metacognitive Strategies

According to Table 6, the effect of the Conscientiousness trait was greater than the effect of the Openness to Experiences trait to change the overall Metacognitive strategy use, because of the obtained Beta for the Conscientiousness trait showed that for each of one unit of value of change in the Standard Deviation of the Conscientiousness trait, the amount of change .342 occurred in the Standard Deviation of the overall Metacognitive strategy use. However, for the Openness to Experiences trait, for each of one unit of value of change in its Standard Deviation, the amount of change .218 occurred in the Standard Deviation of the overall Metacognitive strategy use. From the above table, it was further evident that for all the predicted models and constants, the $t$ values ranged from 3.466 to 10.364 , which were all found to be significant, and significance levels ranged from .001 to .000 level. 
TABLE 7:

THE EXCLUDED VARIABLESC OF THE EQUATION

\begin{tabular}{|l|l|l|l|l|l|l|}
\hline \multirow{2}{*}{ Model } & Beta In & $\mathbf{t}$ & Sig. & Partial Correlation & Collinearity Statistics & Tolerance \\
\cline { 3 - 6 } 1 Extraversion & $.057^{\mathrm{a}}$ & .845 & .399 & .058 & .905 \\
Openness to Experiences & $.218^{\mathrm{a}}$ & 3.466 & .001 & .233 & .981 \\
Agreeableness & $.027^{\mathrm{a}}$ & .413 & .680 & .028 & .934 \\
Neuroticism & $-.065^{\mathrm{a}}$ & -.965 & .336 & -.066 & .888 \\
\hline 2 Extraversion & $.026^{\mathrm{b}}$ & .399 & .690 & .028 & .888 \\
Agreeableness & $.010^{\mathrm{b}}$ & .149 & .881 & .010 & .928 \\
Neuroticism & $-.039^{\mathrm{b}}$ & -.578 & .564 & -.040 & .876 \\
\hline
\end{tabular}

a. Predictors in the Model: (Constant), Conscientiousness

b. Predictors in the Model: (Constant), Conscientiousness, Openness to Experiences

Dependent Variable: Metacognitive Strategies

Table 7 showed the excluded variables in this equation. The excluded variables in the first step were Extraversion, Openness to Experiences, Agreeableness, and Neuroticism. In the second step, the excluded variables were Extraversion, Agreeableness, and Neuroticism.

In summary, one can conclude that the traits like the Conscientiousness trait, and the Openness to Experiences trait best predicted the overall use of Metacognitive Strategies of the students.

\section{LIMITATIONS OF THE CURRENT STUDY}

Generally speaking, there are some difficulties inherent in endeavor to conduct any research work on the learners of second/foreign language. Such difficulties are as the results of methods(e.g. measurement issues, sampling issues), type of instrumentations (e.g. exclusive reliance on self-report responses to the questionnaires, ambiguity in the questionnaire item wording, response style bias), and the other variables used in conducting this type of research (Ellis, 1985). Similarly, the present study due to using Ex Post facto type of research has certain limitations that must be taken in mind which interpretation of the results.

Moreover, since all the education quasi-research deals with living human beings are occur out of laboratory conditions have limitations (Gall, Gall \& Borg, 2003). Like any study, the current study has a number of limitations. The limitations in this study include limitations that are related to questionnaires, English proficiency test, statistical method, large of sample, type of research, comprehensive operational definitions, environment, and culture.

\section{REFERENCES}

[1] Behling, O., \& Law, K.S. (2000). Translating questionnaires and other research instruments: Problems and solutions. Sage University Papers Series on Qualitative Applications in Social Sciences, 07-131. Thousand Oaks, CA: Sage.

[2] Block, J. (1995). A contrarian view of the five-factor approach to personality description. Psychological Bulletin, 117,187-215.

[3] Brown, H. D. (2001). Principles of language learning and teaching. Englewood Cliffs, NJ: Prentice Hall.

[4] Brown, J. D. (1996). Testing in language programs. Upper Saddle River, NJ: Prentice Hall Regents.

[5] Cattel, R. B., \& Butcher, H. (1968). The prediction of achievement and creativity. New York: Bobbs-Merrill.

[6] Chamorro-Premuzie, T., Furnham, A., \& Lewis, M. (2007). Personality and approaches to learning predict preference for different teaching method. Learning and Individual Differences, 17,241-250.

[7] Cohen, J. (1988). Statistical power analysis for the behavioral sciences ( $2^{\text {nd }}$ ed.). Hillsdale, NJ: Lawrence Erlbaum Associates.

[8] Cohen, A.D., \& Scott, K. (1996). A synthesis of approaches to assessing language learning strategies. In R. L. Oxford (Ed.), Language learning strategies around the world: cross cultural perspectives (pp. 89-106). Honolulu: University of Hawai'I , Second Language Teaching \& Curriculum Center.

[9] Cook, V. (2008). Second language learning and language teaching ( $4^{\text {th }}$ ed.). London: Edward Arnold.

[10] Costa, P.T., \& McCare, R.R.(1988). Personality in adulthood: A six-year longitudinal study of self-reports and spouse ratings on the NEO personality inventory. Journal of Personality and Social Psychology, 54(4), 853-863.

[11] Costa, P.T., \& McCare, R.R.(1992). Professional Manual for the NEO-PI-R and NEO-FFI. Odessa, FL: Psychological Assessment Resources.

[12] Delavar, A. (2010). Theoretical and experimental principle of research in human sciences. Tehran: Roshd Publication.

[13] De Vellis, R. F. (2003). Scale development: Theory and application (2 ${ }^{\text {nd }}$ ed.). Thousand Oaks, California: Sage.

[14] Digman, J. M. (1989). Five robust traits dimensions: Development, stability, and utility. Journal of Personality, 57(1), 195-214.

[15] Digman,J. M., \& Inouye, J. (1986). Further specification of the five robust factors of personality. Journal of Personality and Social Psychology, 50,116-123.

[16] Ehrman, M.E., \& Dornyei, Z. (1998). Interpersonal dynamics in second language education: The visible and invisible classroom. Thousand Oaks, Calif: Sage Publications.

[17] Ellis, R. (1985). Understanding second language acquisition. Oxford: Oxford University Press.

[18] Ellis, R. (1994). The study of second language acquisition. Oxford: Oxford University Press.

[19] Eysenck, H. J.(1967). The biological basis of personality. New York: Springfield.

[20] Eysenck, H. J. (1992). Four ways five factors are not basic. Personality and Individual Differences, 13, 667-673.

[21] Eysenck, H. J.(1997). Personality and exponential psychology: The unification of Psychology and the possibility of a paradigm. Journal of Personality and Social Psychology, 73, 1224-1237. 
[22] Fathi-Ashtiani, A. (2009). Psychological tests: Personality and mental health. Tehran: Be'sat Publication Institute.

[23] Foster, J. J. (1998). Data analysis using SPSS for window: A beginner's guide. Thousand, Oaks, California: Sage Publications.

[24] Gall, M.D., Gall, J.P., \& Borg, W.R. (2003). Educational Research: An Introduction (7 ed.). Boston: Allyn and Bacon.

[25] Ghiasvand, A. (2008). Application of statistics and SPSS in data analysis. Tehran: Lovieh publication.

[26] Goldberg, L. R. (1981). Language and individual differences: The search for universals in personality lexicons. In L. Wheeler(Ed.), Review of personality and social psychology ( Vol.2, pp.141-165). Beverrly Hills, CA: Sage.

[27] Goldberg, L. R. (1990). An alternative description of personality: The big five factor structure. Journal of Personality and Social Psychology, 59, 1216-1229.

[28] Golkar, M., \& Yamini, M. (2007). Vocabulary, proficiency and reading comprehension. The Reading Matrix, 7(3), 88-112.

[29] Hampson, S.E., \& Colman, A. E. (1995). Individual differences and personality. New York: Longman.

[30] Hinkin, T. R. (1998). A brief tutorial on the development of measures for use in survey questionnaires. Organizational Research Methods, 1(1), 104-121.

[31] Horwitz, E. K. (1988). The beliefs about language learning of beginning university foreign language students. Modern Language Journal, 72(13), 283-294.

[32] Horwitz, E. K. (1999). Cultural and situational influences on language learners' beliefs about language learning: a review of BALLI studies. System, 27,557-576.

[33] Hsiao, T-Y., \& Oxford, R. L. (2002). Comparing theories of language learning strategies: A confirmatory factor analysis. Modern Language Journal, 86(3), 368-383.

[34] John, O. P. (1990). The big five factor taxonomy: dimensions of personality in the nature language and in the questionnaire. In L.A. Pervin(Ed.), Handbook of Personality: Theory and Research (pp.66-100). New York: Guliford Press.

[35] Johnson, B.(2001). Toward a new classification of non-experimental quantitative research. Educational Researcher, 30(2), 313.

[36] Kalantari, K. (2008). Data processing and analysis in socio-economic research. Tehran: Farhang Saba Publisher.

[37] Larsen-Freeman, D., \& Long, M. H. (1991). An introduction to second language acquisition research. New York: Longman.

[38] Maleske, R. T. (1995). Foundations for gathering and interpreting behavior data. Pacific Grove, C. A: Brooks/Cole Publishing Company.

[39] Marttinen, M. (2008). Vocabulary learning strategies used by upper secondary school students studying English as a second language. (Online) M.A. Dissertation. Retrieved from20 March, 2010 from https://jyx.jyu.fi/dspace/bitstream/handle/123456789/18447/URN_NBN_fi_jyu200803261288.pdf?sequence=1

[40] McAdams, D. P. (1992). The five-factor model in Personality: A critical appraisal. Journal of Personality, 60,329-361.

[41] McCare, R.R., \& Costa, P.T. Jr. (1985). Updating Norman's adequate taxonomy: Intelligence and personality dimensions in natural language and in questionnaires. Journal of Personality and Psychology, 49,710-721.

[42] Moemeni, M. (2007). Statistical analysis with SPSS. Tehran: Ketab neo Publication.

[43] Newton, R.R., \& Rudestam, K. E.(1999). Your statistical consultant: Answers to your data analysis questions. California: Sage Publications, Inc.

[44] Norman, W. T.(1963). Toward an adequate taxonomy of personality attributes: replicated factor structure in per nomination personality ratings. Journal of Abnormal and Social Psychology, 66, 574-583.

[45] Nunnally, J. C., \& Bernstein, I. H. (1994). Psychometric theory ( $3^{\text {rd }}$ ed.). New York: McGraw-Hill.

[46] Oxford, R. L. (1990). Language learning strategies: What every teacher should know. Boston: Heinle \& Heinle.

[47] Oxford, R. L. (1992). Instructional implications of gender differences in second/foreign language learning styles and strategies. Applied Language Learning, 4(1\& 2), 65-94.

[48] Oxford, R. L. (1993). Individual differences among your ESL students: Why a single method can't work. Journal of English Studies, 7, 27-42.

[49] Oxford, R. L. (1994).Language learning strategies: An update.(Online)Online Resources: Digest. Retrieved $08 \mathrm{March}, 2011$ from http://www.cal.org/resources/digest/oxford01.html

[50] Oxford, R. L. (1996). Employing a questionnaire to assess the use of language learning strategies. Applied Language Learning. $7(1 \& 2), 25-45$.

[51] Oxford, R. L., \& Burry-Stock, J. (1995). Assessing the use of language learning strategies worldwide with the ESL/EFL version of the Strategy Inventory for Language Learning (SILL). System, 23(1), 1-23.

[52] Oxford, R. L., \& Cohen, A. (1992). Language learning strategies: crucial issues of concept and classification. Applied Language Learning, 3(1\& 2), 1-35.

[53] Oxford, R. L., \& Crookball, D. (1989). Research on language learning strategies: methods, findings, and instructional issues. The Modern Language Journal, 73(4), 404-419.

[54] Oxford, R. L. \& Ehrman, M. (1995). Adult's language learning strategies in an intensive foreign language program in the United States. System, 23(3), 359-386.

[55] Oxford, R. L., \& Nyikos, M. (1989). Variables affecting choice of language learning strategies by university students. Modern Language Journal, 73(3), 291-300.

[56] Pallant, J.(2007)( $3^{\text {rd }}$ ed.). SPSS survival manual: A step by step guide to data analysis using SPSS for windows. New South Wales, Australia: Allen \& Unmin.

[57] Perera,M., \& Eysenck, S.B.G. (1984). A cross-cultural study of personality: Sri Lanka and England. Journal of Cross Cultural Psychology, 15(3), 353-371.

[58] Riazi, A.M.(1999). A dictionary of research methods: Quantitative and qualitative. Tehran: Rahnama Publications.

[59] Saklofske, D. H., \& Eysenck, S. B. G. (1998). Individual differences in children and adolescents (Eds.). New Brunswick, NJ. : Transaction Publishers.

[60] Saucier, G., \& Goldberg, L. R. (1996). Evidence for the Big Five in analyses of familiar English personality adjectives. European Journal of Personality, 7, 1-17.

[61] Skehan, P. (1989). Individual differences in second-language learning. London: Edward Arnold. 
[62] Toyoda, E. (1998). Teaching kanji by focusing on learners' developing of graphemic awareness. Australian Review of Applied Linguistics, 21(15), 155-168.

Seyed Hossein Fazeli is pursuing Ph.D. program in linguistics. He has received his M.A. degree in linguistics. His interest includes Language Learning Strategies. Currently he is as a lecturer at Department of English Language Teaching, Abadan Branch, Islamic Azad University, Abadan, Iran 